\title{
Implementation of Industrial Based Islamic Education Management in Pesantren Darussalam Al-Fatah Cilacap
}

\author{
Guntur Dwi Purwanto', Mohammad Ulyan ${ }^{2}$, Abdul Basit ${ }^{3}$ \\ 1,2,3 Institut Agama Islam Negeri Purwokerto, Indonesia \\ 201771018@mhs.iainpurwokerto.ac.id,ulyan@ittelkom-pwt.ac.id,abdulbasit1969@gmail.com
}

\begin{abstract}
Educational management is an important reference in the management of industrial-based Islamic boarding schools. When the management of a leader must go through several things, including planning, organizing, and planning industry-based learning. This research includes a qualitative descriptive approach to da'wah management. The data source used in this research is a literature review. Collecting data in this study using observation, interviews, and documentation. Islamic boarding school Darussalam Al-Fatah Cilacap is an industry-based Islamic boarding school. This was done to follow developments in the industrial revolution 4.0. Therefore, researchers feel it is important for the management of Islamic education at the Darussalam Al-Fatah Islamic boarding school in Cilacap. The results of the application of Islamic education management include, a) soroggan, with the bin-nazhr method, the tahfidz method, the talaqqi method, and the tikrar method, b) taddabur, c) habituation of the Hasbanah and Isyraq prayers, d) rewards for students, $e$ ) the application of industrial learning, and $f$ ) the benefits of evaluating industry-based learning at the Darussalam Al-Fatah Cilacap Islamic boarding school.
\end{abstract}

Keywords

management of Islamic

Education; an industrialbased Islamic boarding school

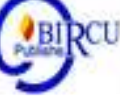

\section{Introduction}

The existence of pesantren in Indonesia is formally recognized based on Law Number 20 of 2003 concerning the National Education System. Article 30 paragraph 4 reads, "Religious education is in the form of diniyah education, pesantren, pasraman, pabhaja samanera, and other similar forms." In this article, it is stated that pesantren functions as an educational unit that prepares students to become members of society who understand and practice the values of their religious teachings and/or become experts in religious knowledge (tafaqquh fiddin).

According to the Big Indonesian Dictionary (2013: 870), management is an activity carried out by managers in managing organizations, institutions, and companies. Besides, Nawawi (1997: 78) reveals that the management of Islamic education is an activity to mobilize and integrate all Islamic education resources to achieve predetermined Islamic education goals.

Tan (2014) in his article reveals that the word pesantren is synonymous with the word surau (in West Sumatra) and dayah (in Aceh), the word pesantren or Pondok pesantren is better known to the people of Java and Kalimantan. Education in Islamic boarding schools includes Islamic education, preaching, community development, and other similar education. Students at the pesantren are called santri. The place where the students live in the pesantren is called the Pondok. From there the term Pondok pesantren emerged (Director General of Islamic Religious Institutions, 2013). Suharto (2016) describes the tri dharma of Islamic boarding schools including, a) faith and devotion to 
Allah SWT; (b) useful scientific development, and (c) devotion to religion, society, and the state.

Zmuda, Alcock, \& Fisher (2017) state that four things are prepared by the teacher before students from the alpha generation enter their learning space, a) focus on skills, not material content, b) Provide learning with greater flexibility and purpose, c ) planning for enhancing collaborative abilities and d) developing soft skills. Gazali (2018) states that Islamic education has three main tasks, which include a) transitioning to Islamic sciences, b) maintaining religion, and c) giving birth to prospective scholars (Azra \& Jamhari, 2006). According to Wiranata (2019), moral damage causes youth to lose their identity, frequent fights, and fights between them.

Pesantren is expected to provide a solution to the decline in morals of youth in Indonesia. Because nowadays the sense of courtesy of young people towards their parents has decreased. One of the signs of this is the development of technology, but the developments that are accepted by young people today are not good enough.

Taufiq (2019) generally reveals that disruption can disturb and cause chaos, but can also provide both stimulation and challenges to be managed positively if faced critically, creatively, and innovatively, depending on the society.

The ideal Islamic education must refer to the basic values of the Koran. The normative value of Islamic education in question consists of three main pillars, namely a) I'tiqadiyyah, this is related to faith education, for example believing in Allah, angels, messengers, books, the Last Day, Judgment, and destiny which aims to organize individual beliefs; b) Khuluqiyyah, this hali is related to ethical education, which aims to rid oneself of inferior behavior and decorate oneself with praiseworthy behavior; and c) Amaliyyah, this is related to daily behavior education, both related to religious education and muamalah education (Hidayat \& Wijaya, 2017: 2)

A leader must have a variety of experiences, this is useful for overcoming various problems related to everything in his boarding school. According to Firdaus, Purnamasari, \& Akuba (2019), leadership is an ability that influences others to achieve goals in certain situations. Besides, Hakim (2019) adds that leadership in the management concept can be understood as a concept in the organizational process which has a strategic position and social interaction for group life..

A leader must create harmonious social interactions with its members, so that they can achieve the goals and objectives that have been planned and compiled together. A leader cannot walk alone to do every job, between members and superiors there must be openness to one another, it aims to reduce suspicion and increase trust in an organization. A leader can at least show a sympathetic attitude in carrying out his duties, besides checking the work of his members (Samsirin, 2015). Besides, Hafidh et al (2019) in their research concluded that one of the determining factors for the success of the pesantren was by transforming the Kiai's leadership patterns to build the pesantren's vision and mission.

When i visited several pesantren, during the process of gathering I saw the very lack of active members, either to ask questions or to convey opinions or suggestions. A leader must exemplify openness to members or all of the academic community in the boarding school environment. Openness in the sense here is not only accepting suggestions / complaints from members but also training the courage to be free of opinion. A leader is encouraged to accept all input or suggestions from its members. This is done to create closeness between the leader and its members. Furthermore, Kurniawan (2015) in his research explained that the Al-Qur'an has provided a foundation for Muslims to be honest and fair, which is the key to openness. This is also stated in Surah An-Nisa verse 58. 
Sakti (2020) states that according to Islamic teachings the concept of leadership is believed to have transcendental values that are fought for in Islamic leadership in any organization. These values become the basis for leadership activities. Furthermore, Rahmat \& Candra (2017) explained that the Al-Quran defines leadership as an authority exercised by individuals who are very close to the principles in the Al-Qur'an and Al-Sunnah.

In line with this, Rizki et al (2021) revealed that the value of worship is carried out as a form of riyadhah, which is an application that is applied in everyday life as a form of devotion to Allah Almighty. If this is done continuously, it can purify the soul by believing in the truth.

Increasingly, Islamic boarding schools experience developments in terms of education and marketing methods. It is not uncommon today that Islamic boarding schools use their characteristics to attract the attention of students. As stated by Efendi (2017), modern Islamic boarding schools are responsive to changes, for example, learning using Arabic or English as an introduction. In contrast to what Efendi said, the Darussalam Al-Fatah Islamic boarding school in Cilacap had innovation in introducing it to the general world, namely industrybased learning. It is hoped that the Darussalam Al-Fatah Islamic boarding school in Cilacap will be different from other Islamic boarding schools. Apart from keeping up with the times in the field of technology, the Darussalam Al-Fatah Islamic boarding school also has a distinctive character among the general public, namely the industrial-based Islamic boarding school.

Researchers feel it is important to make the management of industrial-based Islamic boarding schools without reducing Islamic values. It is intended that the Darussalam Al-Fatah Islamic boarding school can keep up with the times following its slogan. The challenges that must be faced by pesantren are related to improving the quality of education and being able to answer the challenges of the times. Because, in the era of the industrial revolution 4.0 as it is today, it presents a new face in the social interaction of modern society (Wiranata, 2019).

In line with this, Siswanto (2020) in his article concludes that Islamic boarding schools are faced with the quality of their education having relevance to science and technology development. This can improve the quality of infrastructure education to develop boarding schools as a whole. Researchers feel the need to carry out industrial-based education management to balance the industrial revolution 4.0

Langgulung (2000: 248) explains that there are seven principles of Islamic education management, namely sincerity, honesty, trustworthiness, fairness, responsibility, dynamic, practical, and flexibility. Management of Islamic Education when applied in the context of Islamic boarding schools can be described as follows.

\section{Review of Literatures}

\subsection{Sincere}

Managing a pesantren starts from the deepest heart to learn many things, one of which is learning to be sincere in doing something. Besides, building a pesantren includes carrying out tasks from Allah SWT. In my opinion, patience has no limits, patience trains to wait for something. While sincere, in my opinion, if a sincere person is patient, how can that person be patient and balanced with what he has done and wait for the results sincerely. If the results obtained are following what is expected, receive it with so much gratitude, if the results obtained are not according to what is expected, it means that there is no luck or try to realize it with positive things and always return everything to Allah SWT. Besides being sincere, always try to do it again accompanied by prayer and maximum effort. 
Sincerity is also included in a principle that will encourage us to do our best even though what is processed is sometimes not what we want. To practice sincerity, one of them thinks that what we do is solely a form of worship and hopes for the blessing of Allah SWT. This is also stated in Q.S Al-Araf verse 29.

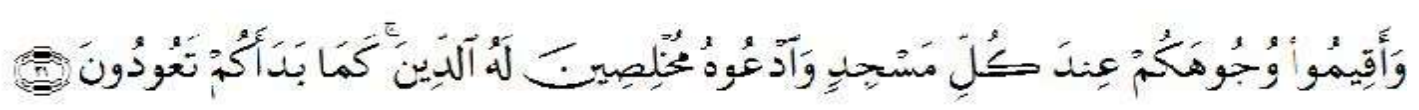

Meaning: And (say): "Straighten your face (yourself) every prayer and praise Allah by giving your obedience to Him. As He created you in the beginning (so too) you will return to Him ". (Surah Al-A'raf: 29).

The verse above invites people to always give up all forms of our personalities solely because of Allah SWT who is accompanied by the belief that Allah SWT will give a reward in kind for that worship. The logical consequence is that if a boarding school is led by someone who has the principle of sincerity for the sake of Allah, surely the pesantren will get the best managerial treatment in all its ways. This will have an impact on the quality of Islamic boarding schools in the future.

\subsection{Honest}

Prophet Muhammad SAW had a very noble character, namely being honest. Honest became an identity by Muhammad Saw during the prophetic period. Until now, they still hold fast and become an example of mankind, especially Muslims. Of course, it becomes uswah for all of us Muslims how important honesty is to be the main asset for a leader. If we look at the current conditions, honesty is very expensive.

Nowadays it is very difficult to find honest people if you try, some people don't like us. This can be indicated by the increasing prevalence of KKN (corruption, collusion, and nepotism) among officials. Starting from state officials to officials among the lower ranks, this happens because of the waning of faith and honesty possessed by a leader.

Several verses of the Al-Qur'an explain honesty.

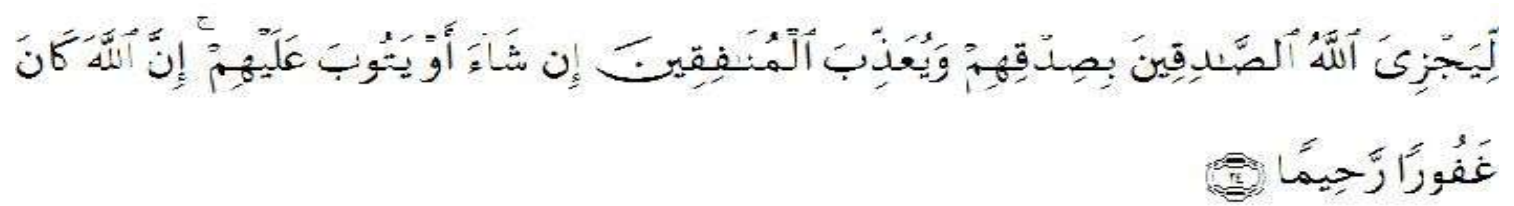

Meaning: "So that Allah will give reward to those who are righteous because of their truth, and torture the hypocrites if He wills, or accept their repentance. Indeed, Allah is Most Forgiving, Most Merciful. "(Surah Al-Ahzab: 24)

The above verse explains that Allah SWT gives rewards to hypocrites with everything that He wants. The above verse also explains that Allah SWT accepts the repentance of hypocrites Allah is all-forgiving and most merciful. Another verse Allah Almighty says.

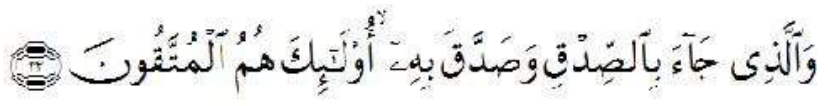

Meaning: "Those who bring the truth (Muhammad) and who justify it, they are pious people.”(QS. Al-Zumr: 33)



Meaning: "O you who believe, fear and let you be with people who are honest"QS. AtTaubah: 119). 


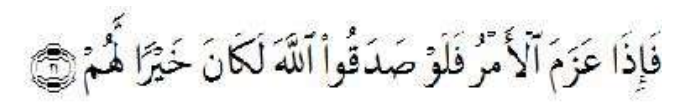

Meaning: "If they are honest with Allah, surely that is better for them"(QS: Muhammad: 21)

The verse above also invites us to always be pious people and to be honest people in all things. Being honest is the best trait possessed by humans. Departing from this in the context of pesantren, honesty, which is a very important principle and key, must be possessed by a leader. A leader of an Islamic boarding school must have the legitimacy to establish many pesantren policies, including in the budget, and will bring the pesantren to be more advanced and modern without reducing the value of Islamic education..

Nowadays, the development of the times is getting more advanced, therefore a leader must think ahead by following the developments in the current technological age. For example, an industrial-based Islamic boarding school, because nowadays people learn, they think of going straight to work. That is where the role of a leader takes the boarding school to a more advanced and modern direction guided by the values of Islamic education. A leader must model honest and open behavior in all things. The consequence is that if the boarding school is led by an honest manager, of course, the boarding school will get rights or results following the designation given to it. Besides that, it will also get more value among the community.

\subsection{Secure}

Islam teaches and explains that the position is merely a mandate that must be accounted for. This accountability is not only in this world but also in the hereafter to Allah SWT. Amanah can be interpreted as trust, so someone who is given a mandate is one who has the trust to hold and carry out the task he is assigned to. Allah Most High said:



Meaning: "Verily Allah told you to convey the message to those who have the right to receive it, and (ordered you) when establishing laws among humans so that you determine fairly. Verily, Allah has taught you the best. Indeed, Allah is All-Hearing, All-Seeing. "(Surah An-Nisa '/ 4: 58)

\subsection{Fair}

One of the important principles in the management of Islamic education is fairness. According to Abuddinnata (2003: 144) justice is a term used to show equality or being in the middle of two cases. Acting fairly is highly recommended in everyday life, especially if a leader must be able to be fair to something in front of him. Leaders are required to have fair principles so as not to foster a sense of social jealousy. Fair is also an indicator of someone's piety. Allah Most High said.

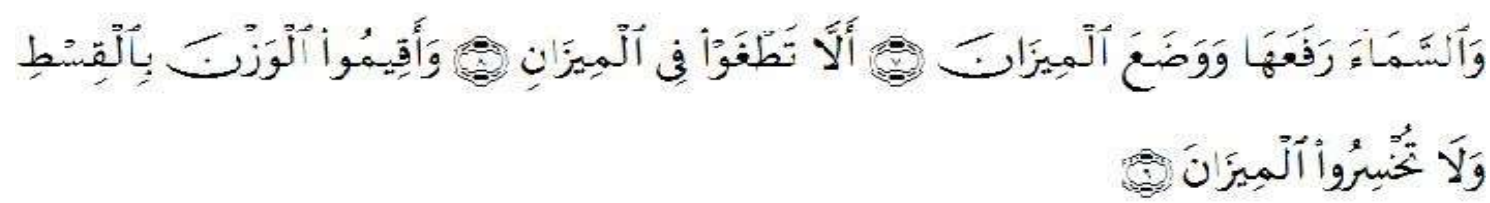

Meaning: "And Allah has lifted the ceiling and He put a balance (justice) so that you do not go beyond the balance of the balance. And uphold the balance fairly and do not reduce the balance ".(QS. Ar-Rahman, 7-9). 
Apart from that, in the Al-Qur'an surah Al-Maidah verse 8, Allah also says:



Meaning: "O you who believe, let you be the ones who always uphold (the truth) because of Allah SWT, be a just witness. And never let your hatred of a people cause you to be unjust. There is justice because justice is closer to piety. And be pious to Allah SWT. Indeed, Allah SWT. All-Knowing of what you do".(QS. Al-Maidah: 8).

In the context of pesantren, justice often causes conflict while injustice does not materialize. This is where the task of a leader must be responsible for providing justice to students. Responsibility is the management part of a leader to bring about justice. In the management of Islamic education, justice should be the main principle possessed by a pesantren leader.

\subsection{Responbility}

Responsibility is one of the principles of Islamic education management that must be carried out in trust to build positive management. Allah SWT says.

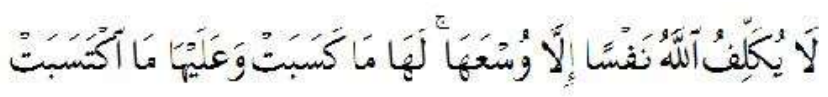

Meaning: "God does not burden a person except according to his ability. He will be rewarded for what he did, and he will be rewarded for what he did.."(QS. Al-Baqarah: 286).

The above hadith explains that the main task of a leader is to lead himself. When he can lead himself then lead others. A leader in carrying out his duties is required to be a responsible person, intelligent, strong, independent, true, firm in his stand, and wise as a leader. Therefore, a pesantren hut leader must have an attitude of responsibility for the task he carries.

Many scientists view strategic management as art in formulating, implementing, and evaluating the organization's cross-functional decisions to achieve their goals. The explanation is very open to our eyes to freely express what is in everyone's idea, as long as it is balanced with the knowledge they have (Fauzi, 2020).

Fattah (2008: 11) explain that the importance of the basic principles of management practice among others, a) determine the way/method of work; b) the selection of employees and the development of their membership; c) selection of work procedures; d) determine the task boundaries; e) prepare and make task specifications; f) conduct education and training, and g) determine the system and amount of rewards. All of them are intended to increase effectiveness, efficiency, and work productivity.

\section{Research Methods}

The method in this research is library research and the data source used comes from a documentative study of data sources consisting of literature related to the theme of industrialbased Islamic boarding school education management. Data processing in this study uses descriptive-analytical methods, namely a research model that seeks to describe, record, analyze, interpret existing phenomena so that it is expected to provide descriptions to industrial-based Islamic boarding schools. 


\section{Description of Islamic Education Management Functions in Islamic Boarding Schools}

\section{a. Planning}

Planning would be better to pay attention to the education system in these schools by studying existing activities. A leader must be able to analyze things that are rational and systematic in the process of educational development in an institution. This was done to make it more effective and efficient in responding to the needs and goals of the students and the academic community living in the boarding school environment.

A leader before taking a plan would be good to pay attention to what must be done and for whom the plan. The same is the case with selecting several activity designs and seeing what to do, for whom the activities are, how the activities work, whether they can run optimally and produce the expected results.

Planning must consider the conditions of time, where plans and activities will be carried out in stages according to the plans that have been made. Planning is one of the most important aspects of management. A leader must be able to see the conditions according to the times. Besides, a leader must be able to see the needs of the community, one of which is by looking at several Islamic boarding schools. A leader is always required to think forward, this is to see opportunities in society, basically the goal of parents to send their children to school so they can quickly get a job. However, if a Muslim leader plans something, it must be based on the guidelines of the Koran and Hadith.

As explained by Soetomo and Sumanto (2005: 35-36) there are several uses for planning, include 1) planning includes efforts to set goals or formulate objectives to be selected; 2) planning allows knowing the objectives to be achieved; and 3) can identify the obstacles to be faced. Usman (2010) also explains that there are several benefits of planning for a boarding school, including obtaining standards for supervision and control, making priorities, estimating implementation, minimizing unproductive activities, etc.

Besides, there are several efforts to improve the effectiveness of educational planning, this includes 1 ) every plan must be broad and open to receiving suggestions from others; 2 ) every plan must be about what overall is needed for mutual progress; 3) every plan must think long and sustainably, this is done so that a leader is required to think based on the progress of the times; 4) every plan must look at something that has happened and learn from the shortcomings that have occurred during the joint evaluation; 5) every planning should be based on efficiency; and 6) every planning made by a leader must be assisted by an efficient administrative organization and combined with reliable data, because basically when a leader has planned something, it cannot run independently without organizational help.

A leader in compiling a plan must be based on a careful calculation of resources so that the planning is successful according to the expected goals. In the Koran, several things mention educational planning, one of which is in Q.S Al-Kahfi [18]: 103-104, which means "Say: will we tell you about the people who suffer the most losses? Namely, people whose deeds are futile in the life of this world, while they think that they are doing their best.

\section{b. Organizing}

After planning the next activity is organizing. The organizational system of working groups of people to achieve the same goal. Organizing determines functions related to the scope of activities to be carried out. It aims to maximize work division following the task at hand. The work fields are arranged based on a complete structure according to their respective phenomena. It does not mean working individually but strengthening each other in all things to get the maximum results as expected. Some forms of organizational implementation must be intact, compact, loyal friends, open to receiving suggestions so that activities run smoothly and easily to achieve goals according to common expectations. 


\section{c. Industry Based Learning Planning}

Industry-based learning planning at the Darussalam Al-Fatah Islamic boarding school in Cilacap includes the following activities, 1) the planned material must be following the theme, namely combining existing materials in the Darussalam Al-Fatah Islamic boarding school with industrial needs; 2) educators who will provide training, it would be better if they had to follow the training provided by the partner industry; and 3) determining the learning method used must be following the times, especially the students who will be taught in the industrial sector. The methods taught by educators can be through PowerPoint videos, instructional videos, industrial visits, internships, practice, and production. In this Cofid-19 pandemic season, educators may be able to share videos and materials through online applications, this is to make it easier for students to obtain material.

\section{Results and Discussion}

Application of Industry - Based Management at the Darussalam Al-Fatah Islamic Boarding School, Cilacap

There are several applications of industrial learning in the Darussalam Al-Fatah Islamic boarding school in Cilacap, these include:

\section{a. Sorogan}

The first learning strategy carried out at Pondok Pesantren Darussalam Cilacap was sorogan. Sorogan is a religious activity that is instructed by educators/ustadz to students to advance one by one in front of the ustaz to be listened to read the Quran. After several students had advanced, the ustad formed a group. Each group consists of 5/6 students. After forming groups between students with each other, students are then assigned to assess each other and deliver about which part of the reading was not correct. This is done to train discussions between one student and another, in addition to increasing the closeness between the students.

The method used in this method is the bin-nazhr method, that is, before memorizing the AlQur'an the students are given about 20 minutes to carefully read the verses of the Al-Qur'an which will be memorized by looking at the mushaf repeatedly. After performing the bin-nazhr method, the ustad performs the tahfidz method, where the students are allowed to memorize the verses of the Al-Qur'an little by little that have been read over and over again. Furthermore, the ustadz used the talaqqi method, in which the students deposited the memorization of Al-Qur'an to the ustadz in turn. After all the students have deposited their memorization, the next method is carried out by utadz, namely the tikrar method, this method assigns the students to recite the Al-Qur'an memorization until they are completely memorized.

To be sustainable, every day ustadz uses the ziyadah method, this activity is a process of adding new memorization. This was done so that the students were still active and had a target of memorizing the Qur'an. After that, the ustadz also used the muroja'ah method, this activity was a process of repeating old memorization, the meaning of old memorization here was memorization that had been done before. This is done so that the students can memorize and easily forget the AlQur'an memorization that has been done. This activity is carried out every day routinely before the industrial learning process takes place.

\section{b. Tadabbur}

Tadabbur is a step after reading and memorizing the Al-Qur'an. This step is continued by trying to uncover, understand, and reflect on the meaning contained in the Al-Quran. After understanding and contemplating trying to practice in everyday life and invite the general public. 
This was done by Ustadz against the students after the sorogan process. This process aims to train the students' sensitivity to the life around them, especially the environment of the Darussalam AlFatah Cilacap Islamic boarding school. Besides, the students are expected to have care between one santri and another, this is done to minimize friendship rifts between the students.

Besides that, memorizing verse by verse aims to always keep the memorization so that it is not forgotten and increase the insight of the students. This activity can be said to be the direct practice of the students after gaining knowledge, whether the students have practiced it optimally as recommended or not. After I made observations, it turned out that the students had done the tadabbur optimally, although gradually. In my opinion, it is good, because the students have made progress towards goodness.

\section{c. Habituation of Hasbanah and Isyraq Prayers}

The book Abwabul Faraj explains that the Hasbanah prayer is a prayer for two rak'ahs. The procedure for this Hashanah prayer is done every cycle after reading the Al-Fatihah letter followed by reading "Hasbunallah Wa Ni'al Representative" 450 times. The practice of this prayer aims to ask Allah SWT for help and protection from various things that are displeased or dangerous.

Isyraq prayer is also called dhuha prayer because it is performed at the beginning of dhuha time, and the time is short. Because this prayer is done after the sun rises and rises one spear of the sun approaching the middle.

The practice of the Hasbanah and Isyraq prayers is aimed at training the discipline of the students. Ustaz hopes that by modeling the hasbanah and Isyraq prayers that are carried out continuously and routinely, the students can imitate and practice them directly.

\section{d. Reward for Santri}

A reward is a form of appreciation by the Ustaz given to the students because they have studied well and correctly. Besides, the reward also aims to increase the motivation of the students in all activities in the Darussalam Al-Fatah Islamic boarding school, Cilacap. The reward can be done by giving praise or giving gifts in the form of something they need.

Not only memorizing letters but also rewarding other activities. It aims to increase the spirit of the students to become even better people. Before the Ustaz gave the reward, before giving several assignments, each student got his assignment. After there is a time limit, the students are encouraged to report to the Ustaz about what responsibilities he has done. In addition to training the responsibilities of the students, this also trains the honesty of each student. The prizes for each student are different, some are in the form of clothes, shoes, bags, Al-Qur'an, Yassin, and many other kinds of gifts.

\section{e Application of Industry-based Learning at the Darussalam Al-Fatah Islamic Boarding School, Cilacap}

The initial stage of industrial learning was carried out at the Darussalam Al-Fatah Islamic boarding school in Cilacap, namely the learning stage by practicing religion, as explained above. These activities include:

1) Material presentation, namely presenting material to class XI students, is because class XI will carry out industrial work practices. This presentation also aims to provide students with later practice, so that students do not understand anything. The task of educators is to use a variety of methods when explaining, as long as students understand their respective industrial majors. Educators provide opportunities for students to ask questions about material that they do not understand, after collecting a few questions, educators hold discussions with students. In addition to training students' courage, it also trains students to be confident. 
2) Conducting industrial visits with partners, this activity is a contextual learning activity/learning outside the classroom by conducting industrial visits, there have been several industrial visits that have been carried out, including Astra Honda Motor, Daihatsu, and Telkom Indonesia. This industrial visit with partners aims to train students' skills so that they can better master the material and be skilled in their respective fields. This is very important because it provides provisions for practical work in the field.

Industry visits include contextual learning outside the classroom. This is done so that students do not feel bored accepting the material only. It would be nice to have less material but prioritize practice. The industrial visit is following the counterpart. Before visiting industrial colleagues, make pilgrimages first, because basically, a Muslim must know the graves of the saints who have preceded him. After making a pilgrimage to the guardian's grave, then do industrial visits. From there, students do not only learn Indonesian culture but also prioritize religion.

3) After the partner industry visit, students are assigned to make related reports during industry visits, because in the Cofid-19 pandemic all learning is online, one of which is using the zoom application. This application can be used by educators and students for the learning process, besides this application can also be used for discussions related to industrial material. Industrybased learning at the Darussalam Al-Fatah Islamic boarding school in Cilacap also uses the characteristics of learning to know, namely learning is not only oriented towards learning outcomes, but must also be oriented towards the learning process.

\section{f. Evaluation of Industry-based Learning at the Darussalam Al-Fatah Islamic Boarding School, Cilacap}

The benefits of evaluating learning we can find out the problems that exist during the learning process. This problem can be arranged for further planning. There are several functions of conducting learning evaluations, these include (1) being able to find out the performance of each student during industrial visits, especially in the field of security and visits to industry colleagues; and (2) can plan the type of improvement following the problems that exist in students during industrial visits, the problems faced by students can be used as solutions to be more advanced.

Sincerity here means doing all activities during the learning process sincerely without strings attached. After that, it is appropriate for every educator to have an honest character. It can also provide an example for students. A leader of a boarding school must be trusted because he has been given a very extraordinary task. The task must be carried out according to existing rules. A leader must also have a fair attitude, this fair attitude can minimize social jealousy. It is also important that a leader must have is responsibility. A leader must be able to manage his boarding school based on Islamic values.

A leader must exemplify the character of sincerity, honesty, trustworthiness, fairness, and responsibility in his daily activities. It aims to train its members so they are not surprised. The members here are the educators / Ustaz. After the Ustaz performs and observes the characters that have been exemplified by their leaders and then emulated again to their students, the hope is that this positive character will continue to run forever.

\section{Conclusion}

Based on the description above, it can be concluded that the management of industrial-based Islamic education at the Darussalam Al-Fatah Islamic Boarding School in Cilacap includes planning by a boarding school leader, organizing with the entire academic community of the Darussalam Al-Fatah Cilacap Islamic boarding school, as well as planning for industry-based 
learning at the Islamic boarding school. pesantren Darussalam Al-Fatah Cilacap. Besides, the application of industrial learning at the Darussalam Al-Fatah Islamic boarding school in Cilacap includes (a) Sorogan, a Quran memorization activity carried out by the students. The methods used in this activity are the bin-nazhr method, the tahfidz method, the talaqqi method, and the tikrar method; (b) Taddabur, this activity is carried out after sorogan, namely by trying to uncover, understand, contemplate the meaning and practice it in everyday life; (c) habituation of Hasbanah prayers and Isyraq prayers; (d) rewards for students; (e) application of industry-based learning at the Darussalam Al-Fatah Islamic boarding school, Cilacap, including material presentation, conducting industrial visits, reporting industrial visits online or using the zoom application; and (f) the benefits of evaluating industry-based learning at the Darussalam Al-Fatah Islamic boarding school in Cilacap, among others, being able to find out the performance of each student and being able to plan types of improvements tailored to existing problems.

\section{References}

Abuddin Nata. 2003. Akhlak Tasawuf. Jakarta: Raja Grafindo Persada.

Departemen Pendidikan Nasional. 2013. Kamus Besar Bahasa Indonesia Pusat Bahasa.. Jakarta: PT. Gramedia Pustaka Utama.

Dirjen Kelembagaan Agama Islam. 2013. Pondok Pesantren dan Madrasah Diniyah: pertumbuhan dan perkembangannya. Jakarta: Departemen Agama RI.

Efendi, Arief. 2017. Model Pengelolaan Pendidikan Multikultural di Pondok Pesantren Tradisional Modern. Journal of Islamic Education Management. Vol. 3, No. 1. Hlm. 120.

Fattah, Nanang. 2008. Landasan Manajemen Pendidikan. Bandung: Remaja Rosdakarya.a

Fauzi, Farid. 2020. Impelemntasi Manajemen Strategis pada Program School Improvement di MTS Maqama Mahmuda. J-MPI (Jurnal Manajemen Pendidikan Islam). Vol 5, No. 1. Hal.26-43.

Firdaus, R.A., Purnamasari, D., Akuba, S.F. 2019. The Influence of Motivation, Leadership, and Perceived Workload as Intervening on Teacher Commitmen. Journal of Education Scholarship Development Enterprize. p. 47-53.

Gazali, Erfan. 2018. Pesantren Di Antara Generasi Alfa dan Tantangan Dunia Pendidikan Era Revolusi Industri 4.0. OASIS: Jurnal Ilmiah Kajian Islam, Vol 2, No 2.

Hafidh, Zaini. Zuhri, M. Tajudin \& Sandi, Wawan Kurniawan. 2019. The Role of Kiai Leadership and Character Education: a Pattern of Santri Character Formation at AsSyifa Al-Qur'an Islamic Boarding School. Journal Of Leadership In Organizations. Vol. 1, No. 2. 134-145.

Hakim, M.N. 2019. Manajemen Masyarakat dalam Mengembangkan Lembaga Pendidikan (Studi Kasus di SMK Negeri 1 Dlanggu Mojokerto). Nidbomul Haq: Jurnal Manajemen Pendidikan Islam. Vol. 4. No.2. Hlm. 201-205.

Husaini, Usman. 2010. Manajemen Teori, Praktik, dan Riset Pendidikan. Edisi 3. Jakarta: PT Bumi Aksara.

Kurniawan, Sugeng. 2015. Konsep Manajemen Pendidikan Islam Perspektif Al-Qur'an dan Al-Hadits (Studi tentang Perencanaan). Jurnal Nur El-Islam. Vol, 2. No, 2.

Langgulung, Hasan. 2000. Asas-Asas Pendidikan. Jakarta: Al-Husnah

Nawawi, Hadari. 1997. Administrasi Pendidikan. Surabaya: CV. Haji Mas Agung.

Rahmat, Hidayat \& H. Candra, Wijaya. 2017. Ayat-Ayat Alquran tentang Manajemen Pendidikan Islam. Medan: LPPI.Samsirin. 2015. Konsep Manajemen Pengawasan dalam Pendidikan Islam. Jurnal At-Tadib. Vol. 10, No.2. Hlm. 342-360. 
Rizki, Achmad. Hamat, Anung Al \& Muhyani. 2021. Model Pendidikan Kepemimpinan Berbasis Tazkiyah Al Nafs. Islamic Management. Jurnal Manajemen Pendidikan Islam. Vol 4, No. 1. Hlm. 139-167.

Siswanto. 2020. The Quality Management of Islamic Boarding School Based on Information Technology in the 4.0 Industry Era. Ijtimaiyya: Journal of Muslim Society Research. Vol, 5. Numb. 1. P.37-47.

Soetomo, Hendiat dan Sumant, Wasti. 1982. Pengantar Operasional Adminstrasi Sekolah. Surabaya: Usaha Nasional.

Suharto, Edi. 2014. Membangun Masyarakat Memberdayakan Rakyat ( Kajian Strategis Pembangunan Kesejahteraan Sosial dan Pekerjaan Sosial). PT. Refika Aditama

Tan, C. 2014. Education Tradition and Islamic Schools in Indonesia. Journal of Arabic and Islam Studies. Vol.14, 47-62.

Taufiq, Ahmad. 2019. Pengembangan Kesadaran Kritis diPesantren dalam Mengahadapi Tantangan Revolusi Industri 4.0. Prosiding Nasional, Vol,2.

Wiranata, RZ Ricky Satria. 2019. Tantangan, Prospek, dan Peran Pesantren dalam Pendidikan Karakter di Era Revolusi Industri 4.0. Jurnal Komunikasi dan Pendidikan Islam. Vol, 8. No 1.

Zmuda, A., Alcock, M., \& Fisher, M. (2017). Meet Generation Alpha: Teaching the Newest Generation of Students. 